\title{
Mason Codes
}

National Cancer Institute

\section{Source}

National Cancer Institute. Mason Codes. NCI Thesaurus. Code C19191.

Functional category code. 